\title{
VIOLENCIA NOBILIARIA EN EL SUR DEL REINO DE VALENCIA A FINALES DE LA EDAD MEDIA ${ }^{1}$
}

\author{
Santiago Ponsoda López de Atalaya \\ Juan Leonardo Soler Milla
}

\section{RESUMEN}

Los conflictos señoriales constituyeron uno de los rasgos definitorios del proceso de señorialización en el País Valenciano durante los siglos bajomedievales. En este trabajo se analizan dos casos paradigmáticos, las disputas entre los Maça de Liçana y Roiç de Corella y la bandositat entre los Rocafull, Rocamora y Masquefa en las comarcas meridionales, ahondado en la casuística del enfrentamiento entre señores al hilo de la renovación historiográfica valenciana en los estudios de la nobleza.

Palabras clave: Nobleza, reino de Valencia, baja Edad Media, conflicto señorial, bandositat, Maça de Liçana, Roiç de Corella, Rocafull, Rocamora, Masquefa.

\section{ABSTRACT}

The seigneurial conflicts constituted a defining feature in the feudal process of the Kingdom of Valencia during the Low Middle Ages. In this work two paradigmatic cases are analysed, the disputes between the Maça de Liçana and Roiç de Corella and the bandositat between the Rocafull, Rocamora and Masquefa in

\footnotetext{
1 Santiago PONSODA LÓPEZ DE ATALAYA.

Licenciado en Historia. Becario de Investigación Predoctoral. Departamento de Historia Medieval, Historia Moderna y Ciencias y Técnicas Historiográficas. Facultad de Filosofía y Letras. Universidad de Alicante. 03080 Alicante. C.e.: santiago.ponsoda@ua.es. Juan Leonardo SOLER MILLA.

Licenciado en Historia. Ayudante. Departamento de Historia Medieval, Historia Moderna y Ciencias y Técnicas Historiográficas. Facultad de Filosofía y Letras. Universidad de Alicante. 03080 Alicante. C.e.: Leonardo.soler@ua.es.
} 
the southern regions, and it looks in detail at the casuistry of the confrotation between the Lords in the thread of the historiographic renewal of Valencia in the study of the nobility.

Keywords: Nobility, Kingdom of Valencia, Low Middle Ages, seigneurial conflict, bandositat, Maça de Liçana, Roiç de Corella, Rocafull, Masquefa.

La nobleza, a pesar de ese sesgado y genérico conocimiento muchas veces ofrecido desde medios como la Literatura, el cine o la propia Historia, no ha gozado de muchos estudios históricos o científicos al menos en el ámbito valenciano, tal y como recordaba no hace mucho tiempo Enric Guinot ${ }^{2}$. Los trabajos que habían precedido a los de las dos últimas décadas visualizaron en aspectos a veces muy singulares, si queremos analizar la estructuración de un grupo político, sus estrategias internas y su relación amistad-confrontación tanto con la monarquía, es decir la manida dicotomía monarquía-nobleza, como con los súbditos de estos últimos, los campesinos, en la vertiente de la cuestiones jurisdiccionales y la imposición de la rentas feudales y servidumbres.

Una visión del panorama bibliográfico nos proporciona una imagen positiva donde priman unos trabajos ya clásicos y otros más recientes, que por documentación, metodología y tratamiento conciben este amplio tema de la nobleza como un objeto historiográfico coherente y lo sitúan dentro de un debate epistemológico más moderno. La variedad y complejidad de esta temática, señores y señoríos, engloba múltiples conexiones analíticas que atañen a diversos ámbitos como el estudio de las jurisdicciones desde un enfoque institucional o social, cuestiones impositivas, económicas y tantos otros, lo que dificulta muchas veces obtener una visión conjunta por ser un objeto tan poliédrico. Además, este hecho imposibilita ofrecer una síntesis ya sea bibliográfica o analítica sin conocer en profundidad el propio funcionamiento de los señoríos valencianos. Sin embargo, el panorama investigador en la nobleza peninsular ha conocido un fuerte avance desde mediados de la centuria anterior, el cual continúa en el presente, como lo demuestran los recientes trabajos de Alfonso Franco, Concepción Quintanilla y Rafael Sánchez Saus, por citar algunos ejemplos conocidos³.

2 GUINOT RODRÍGUEZ, E., «Aproximació a la noblesa valenciana en la segona meitat del segle XV», en XVI Congreso de Historia de la Corona de Aragón, Vol. I, Nápoles, 2000, pp. 899-901.

3 FRANCO SILVA, A., Señores y señoríos: siglos XIV-XVI. Jaén. 1997. Ídem, En la Baja Edad Media: (estudios sobre señoríos y otros aspectos de la sociedad castellana entre los siglos XIV y XVI), Jaén, 2000. Ídem, Estudios sobre la nobleza y el régimen señorial en el reino de Castilla: (siglos XIV-mediados del XVI). Cádiz. 2005. SÁNCHEZ SAUS, F., La nobleza andaluza en la Edad Media. EUG. Granada. 2005. Ídem, Las élites politicas bajo los Trastámara. Poder y sociedad en la Sevilla del siglo XIV. Sevilla. 2009. QUINTANILLA RASO. Mª. C., Títulos, grandes del Reino y grandeza en la sociedad política: fundamentos en la Castilla medieval. Madrid. 2006. Ídem. La nobleza señorial en la Corona de Castilla. EUG. Granada. 2008. 
Desgraciadamente este conocimiento para el observatorio valenciano lo comenzamos a tener desde hace relativamente poco tiempo puesto que estos temas quedaron relegados durante la década de los sesenta y setenta del siglo pasado a los historiadores modernistas. Lo cual nos conduce a considerar que la falta de investigaciones en este campo es más que patente y que sólo en los últimos veinte años se han puesto las bases para futuras aproximaciones. Es así que desde mediados de la década de los años ochenta, momento muy relevante para la historiografía valenciana por aparecer las primeras publicaciones sobre esta temática, se produce una auténtica renovación metodológica y una paulatina inclusión de estos ámbitos de estudio en el universo científico de la Corona de Aragón ${ }^{4}$. Penetraba muy tardíamente aquello que en otros espacios, universidades, obras, trabajos, seminarios, se insistía desde tiempo atrás: el feudalismo o feudalismos, el sistema feudal, la renta feudal y otras fórmulas. Procesos, categorías, conceptos, vocablos que unidos a un utillaje metodológico fresco, moderno y serio actualizaban la historiografía valenciana ${ }^{5}$.

4 FURIÓ DIEGO A. y GARCÍA-OLIVER F., «El feudalismo medieval valencià: un assaig d'interpretació», en Debats, n 5, Valencia, 1983, pp. 33-42. (Versión ampliada de Ídem, «Algunas consideraciones acerca del feudalismo medieval valenciano», en Homenaje a Tuñón de Lara, Madrid, 1981, vol. 1 pp. 109-122). Ídem, «Dificultats agràries en la formació i consolidació del feudalisme al Pais Valencià», en La formació i expansió del feudalismo català, Homentage a Santiago Sobrequés i Vidal, Estudi General, 5-6, 1985-1986, Gerona, pp. 291-310; GUINOT RODRÍGUEZ, E., «Origen i evolució del feudalisme al Maestrat de Casteló (ss. XIII-XV)», en La formació i expansió del feudalismo català, Homentage a Santiago Sobrequés i Vidal, Estudi General, 5-6, Gerona, 1985-1986, pp. 311-323; algo posterior; Ídem, «El modelo de feudalismo repoblador: rentas y señoríos en la Valencia bajomedieval», en E. SARASA SÁNCHEZ y E. SERRANO MARTIN (eds.), Señorío y feudalismo en la Península Ibérica (ss. XII-XIX). Zaragoza, 1993, Vol. III, pp. 513-525. de forma más reciente y sintético: Ídem «La implantació de la societat feudal al País Valencià del segle XIII: la gènesi de les senyories i l'establiment de les terres» en El temps i l'espai del feudalisme (Reunió científica. VI Curs d'Estiu Comtat d'Urgell, Balaguer, 11, 12 i 13 de juliol de 2001), Lleida, 2004, pp. 421-442. Ídem, «Els senyorius de la noblesa valenciana a l'època de Pere el gran (1276-1285)», en Estudios en recuerdo de la profesora Sylvia Romeu Alfaro, Valencia, 1989, pp. 489-502. Ídem, «Donamus i concedimus vobis» Monarquia i senyorialització del patrimoni reial al País Valencià en temps de Jaume II», en XV Congreso de Historia de la Corona de Aragón. El poder real en la Corona de Aragón, tomo I, vol. 2, Jaca, 1994, p.221-235. GARCÍA-OLIVER, F., «Estructura agrària i crisi rural. La Corona d'Aragó en el tombant de l'Edat Mitjana», en E. SARASA, E. SERRANO, La Corona de Aragón y el Mediterráneo. Siglos XV-XVI. Zaragoza, 1997, pp. 41-61.

5 FURIÓ DIEGO, A., «De la autarquía al intercambio: la historia medieval valenciana entre 1939 y 1989», en Hispania, 175, Madrid, 1990, pp. 903-920; Ídem, «La historia valenciana medieval: un itinerari historiogràfic», en Millars, XIII, Castellón, 1990, pp. 3-80. Desde el ámbito rural: GUINOT RODRIGUEZ, E., «Feudals i camperols: el marc de les relacions senyorials en el món rural valencià», en Millars, XIII, Castellón, 1990, pp. 81-86. Una de las últimas visiones sobre el feudalismo valenciano: VICIANO NAVARRO, P., «La recerca sobre el feudalisme català medieval: un assaig des de la perifèria», en Afers: fulls de recerca i pensament, Vint anys d'historiografia als Països Catalans, Vol. 20, No. 50, 2005, Valencia, pp. 43-71. 
Un país plé de senyors, así reza uno de los capítulos de una obra todavía clave para entender el feudalismo valenciano, hablamos de Terra de Feudals, editada en 1991, cuya lectura o relectura produce de nuevo la misma sensación de renovación para el historiador actual que por aquellos momentos, ya que mantiene, asimismo, muy vigentes algunos planteamientos, debates, y lo más difícil, posibles vías de análisis. Su autor, Ferran García como han hecho otros, esbozaba a la nobleza catalana y aragonesa, que en años venideros ocuparían y dominarían todo el rural, como ansiosa en su deseo de cruzar el Sènia. El sharq al-Andalus se presentaba como un vasto horizonte donde se concentraba el deseo de muchas indulgencias y botín. La nobleza conocía perfectamente que la fortuna radicaba en la figura del monarca que a su vez articulaba todo el proceso colonizador cristiano a los andalusíes. El rey sabía de la necesidad de señores y órdenes militares para la repoblación pero entendía a su vez el peligro que podían ocasionar estos individuos, como lo perpetraban en tierras de la Corona tiempo atrás. De hecho, el Conquistador más de una vez pensó en ello, dejándolo bien claro: «Al món no ha tan soberg poble com son els cavallers». Fruto de lo cual fue el debilitamiento de los núcleos señoriales en el Doscientos; muchos señoríos, si se permite la expresión, comprendían sólo una alquería o un espacio muy reducido, muchas veces con tierras dispersas en varias comarcas: imposibilitando una gestión racional y económica de los mismos ${ }^{6}$. Imagen y realidad que también ha sido planteada para los señoríos de la Montaña y las Marinas por los profesores Josep Torró ${ }^{7}$, Enric Guinot ${ }^{8}$ y José Vicente Cabezuelo desde los momentos de la conquista hasta la muerte de uno de los grandes señores valencianos del siglo XIV, Bernat de Sarrià ${ }^{9}$. No nos corresponde trazar una evolución que ya ha sido planteada en un extraordinario dossier de la Revista d'Història Medieval «Les senyories medievals. Una visió sobre les formes del poder feudal», publicado en el año 1997, por los profesores E. Guinot, A. Furió y F. García-Oliver. Sin embargo hemos de señalar que la citada dinámica se mantiene al menos hasta fines del s. XIV. La señorialización, por tanto, fue un todo en el País Valenciano durante los siglos bajomedievales aunque la permeabilidad, mutación de dominios, inestabilidad económica fueron sus claves de desarrollo. Además encontramos unos nobles muy ligados a la

6 GARCÍA-OLIVER, F., Terra de feudals. El País Valencià a la tardor de l'Edat Mitjana. Valencia, IVEI, 1991, pp. 67-75

7 TORRÓ i ABAD., J., El naixement d’una colonia. Dominació i resistencia a la frontera valenciana (1238-1276), Valencia, 1999.

8 GUINOT RODRÍGUEZ, E., «L'escenari de les senyories medievals a la comarca de la Marina Alta», en II Jornades d'Estudis "Carmel Giner Bolufer», Pego, 2007, pp. 83-110.

9 CABEZUELO PLIEGO, J.V., Entre el mar y la montaña: Auge y caída del señorío de Bernat de Sarrià, 2011, en prensa, Ídem, "La señorialización de la Montaña (1270-1320)", en Imago Temporis, Medium Aevum, 4, 2011, en prensa. 
actividad militar, función social que nunca perderán, en los tiempos iniciales de la conquista que paulatinamente irán copando cuotas de poder en los organismos e instituciones reales ${ }^{10}$.

Insistiendo de nuevo en el ámbito historiográfico y a tenor de la profusión de estudios de modernistas, como R. Benítez Sánchez Blanco, E. Ciscar, M. Ardit, J. Català, P. Pérez, D. Bernabé entre tantos, hemos de apuntar que se ha producido un claro proceso de acercamiento y análisis de la temática nobiliar, como denotan los trabajos de Pastor Zapata ${ }^{11}$, Pons Alós ${ }^{12}$, Febrer Romaguera ${ }^{13}$, Guinot ${ }^{14}$, o Viciano ${ }^{15}$, por citar ejemplos conocidos. Sólo nos restaría destacar durante estas primeras palabras introductorias dos investigaciones centrales en este marco. En primer lugar, la llevada a cabo por Jorge Sáiz ${ }^{16}$, quien aunque no trate de forma directa este objeto -nos referimos a la violencia nobiliaria- y si la formación de los ejércitos profesionales, ha realizado diversos estudios examinando la transformación social de la nobleza y sus mecanismos de ascensión política y social en relación con la expansión de la monarquía. En segundo, los trabajos de Carlos López Rodríguez que ha radiografiado minuciosamente la nobleza valenciana en el reinado del El Magnánimo, con un ingente caudal de datos, atendiendo a todas las cuestiones: desde

${ }^{10}$ GUINOT RODRÍGUEZ, E., «La creación de les senyories en una societat feudal de frontera: el regne de València (segles XIII-XV), en Les senyories medievals. Una visió sobre les formes del poder feudal. Revista d'Història Medieval, 8, Valencia, 1997, pp. 79-108; FURIÓ DIEGO, A., «Senyors i senyories al País Valencià al final de l'Edat Mitjana», en Les senyories medievals. Una visió sobre les formes del poder feudal. Revista d'Història Medieval, 8, Valencia, 1997, pp. 109-154.

11 PASTOR ZAPATA, J. L., Gandía en la baixa Edat Mitjana: la vila i els senyoriu dels Borja. Oliva (Valencia), 2002.

${ }^{12}$ PONS ALÓS, V., «Los Trastámaras y la nueva nobleza valenciana» en XV Congreso de Historia de la Corona de Aragón. El poder real en la Corona de Aragón, tomo I, vol. 5, Jaca, 1994, pp. 243-256. PONS ALÓS, V. y TRENCHS ODENA, J., «La nobleza valenciana a través de las convocatorias a Cortes (siglos XV-XVI)» en Les Corts a Catalunya. Actes del Congrés d'Història Institucional, Barcelona, 1991, pp. 368-383.

${ }^{13}$ FEBRER ROMAGUERA, M.V., «Un señorío mudéjar al sur de l'Horta de Valencia: la morería de Alcocer», en «Annals de l'Institut d'Estudis Comarcals de l'Horta-Sud», Valencia, 1984, pp. 39-72.

${ }^{14}$ GUINOT RODRÍGUEZ, E., «Aproximació a la noblesa valencia...»

15 VICIANO NAVARRO, P., Catarroja: Una senyoria de l'Horta de València en l'època tardomedieval, Catarroja, 1989; más reciente y recopilación de trabajos; Idem, Senyors, camperols i mercaders. El món rural valencià al segle XV. Barcelona-Catarroja, 2007.

${ }^{16}$ SÁIZ SERRANO, J., «Nobleza y expansión militar de la Corona de Aragón: la nobleza valenciana en las guerras del rey (1420-1448)», en Anuario de Estudios Medievales, 33/2, Barcelona, 2002, pp. 729-780; Ídem, Caballeros del rey: nobleza y guerra en el reinado de Alfonso el Magnánimo, Universidad de Valencia, 2008. Ídem, «La nobleza valenciana en la política expansionista de Alfonso en Magnánimo», en Debats, (Ejemplar dedicado a: Alfonso el Magnánimo y su tiempo), No 104, Valencia, 2009 pp. 58-61. 
su formación, sus relaciones intergrupales marcadas claro está por las alianzas y enfrentamientos, sus actividades económicas: ingresos y gastos ${ }^{17}$. Por tanto, podemos afirmar que se ha pasado de un desinterés a una atención preferente en el panorama historiográfico.

\section{LAS BANDOSITATS: CAUSAS, DESARROLLO, IMÁGENES Y REALIDADES HISTÓRICAS}

Una de las pautas de acción del grupo nobiliar fue la violencia entendida como un motor o un comportamiento sociológico de este grupo político. De esta manera la violencia en sus variados sentidos y comportamientos impregnaba la sociedad, la cultura e incluso las instituciones ${ }^{18}$. Es bien sabido que se trataba de un recurso cotidiano y generalizado entre la nobleza hispánica, entre ellas la valenciana. En este sentido, la reparación de agravios, así como el espíritu vindicativo estaban profundamente arraigados entre los señores del reino del mismo modo que el enojo y la ira eran pautas continuas de sus conductas ${ }^{19}$. Así pues, se puede afirmar que la venganza era uno de los componentes fundamentales de su ética del honor ${ }^{20}$.

Es conocido también que la suspicaz y orgullosa nobleza no siempre necesitó de motivos graves para resolver de forma sangrienta sus diferencias, haciendo caso omiso de la justicia regia. Rencillas de mayor o menor importancia se enlazaban unas con otras, generando odios y afrentas que sobrevivían al paso

${ }^{17}$ LÓPEZ RODRÍGUEZ, C., «Guerras privadas nobiliarias y paz pública en el reino de Valencia (1416-1458)», en LORING, Mª. I. (ed.), Historia Social, pensamiento historiográfico y Edad Media. Homenaje al Profesor Abilio Barbero de Aguilera, Madrid, 1997, pp. 643-667, Ídem. Nobleza y poder político en el reino de Valencia (1416-1446), Valencia, 2005, LÓPEZ RODRÍGUEZ, C. y TORRA PÉREZ, A. «Producción agraria y renta feudal en Valencia (1380-1480), en E. SARASA SÁNCHEZ y E. SERRANO MARTIN (eds.), Señorío y feudalismo en la Península Ibérica (ss. XII-XIX). Vol. III, Zaragoza, 1993, pp. 547-578.

${ }^{18}$ ZORZI A., «La faida fiorenteina: il potere della vendetta», en Medioevo: un passato da riscoprire. Vol. 2, No 5, Milán, 1998, p. 22; SABATE CURULL, F. «Orden y desorden: la violencia en la cotidianidad bajomedieval catalana», en Aragón en el Edad Media, Zaragoza, n 14-15, 2, 1999, pp. 1398-1408.

${ }^{19}$ CABRERA MUÑOZ, E., Fuenteovejuna. La violencia antiseñorial en el siglo XV. Barcelona. 1991. ALFONSO ANTÓN, Ma I., «Litigios por la tierra y «malfetrías» entre la nobleza medieval castellano-leonesa», en Hispania: Revista Española de Historia, Vol. 57, No 197, Madrid, 1997, pp. 917-955; DIAZ DE DURANA ORTIZ DE URBINA, J. R., «Violencia, disentimiento y conflicto en la sociedad vasca durante la Baja Edad Media. La lucha de bandos: estado de la cuestión de un problema historiográfico» en Aragón en la Edad Media: sesiones de trabajo, Zaragoza, 1995, 27-58. DACOSTA, A., Los linajes de Bizkaia en la Baja Edad Media: poder, parentesco y conflicto. Bilbao. 2003. GARCÍA CAÑON, P., «Enfrentamientos interseñoriales en la montaña occidental leonesa afines de la Edad Media» en Miscelania medieval murciana, $\mathrm{n}^{\circ}$ 33, Murcia, 2009, pp. 55-76.

${ }^{20}$ URZAINQUI SÁNCHEZ, S., «Luchas nobiliarias por el control de aguas de riego, tierras de cultivo y pastos durante el reinado de Carlos V», en Estudis, n 32, Valencia, 2006, pp. 195-215. 
del tiempo y afloraban hasta estallar de forma virulenta. La casuística de las motivaciones que alimentaban tales rivalidades y enfrentamientos es múltiple, compleja y variada, aunque rara vez quedase plena constancia de sus raíces ${ }^{21}$. Por añadidura, ocurre con frecuencia que las causas profundas de los conflictos nobiliarios permanecen ocultas bajo el aparato de la movilización de huestes, el ruido de las armas y la emanación de sangre.

Sin embargo, el esfuerzo del historiador conduce a realizar alguna tipología, que aunque sólo sea más formal que argumental en cuanto a las causas, que como ya se ha mencionado se entremezclan y confunden, nos puede ayudar a sistematizar en parte los conflictos. Es así como López Rodríguez ha estimado tres grandes motivos por los cuales se producen estas bandositats, estos enfrentamientos entre nobles, que son los siguientes ${ }^{22}$ :

\section{1. La lucha por la fuerza del trabajo}

En un sistema como el feudal la disputa de los nobles por los vasallos era un elemento ciertamente importante ya que el valor de las rentas, es decir, los ingresos señoriales y la capacidad de trabajo estaban determinadas por el factor de demográfico, esto es, por la fuerza de trabajo de los campesinos puesto que las condiciones técnicas del agro valenciano, salvo en algunos cultivos especiales, era rudimentarias. Por tanto, los nobles rivalizaron por mantener y retener a los campesinos, cristianos y sobre todo mudéjares en sus señoríos, circunstancia que acarreó largas y continuas disputas entre los miembros de este grupo político y también con el monarca, que como cabía esperar actuaba como un señor más.

Las guerras y epidemias, así como los movimientos migratorios, que tuvieron lugar durante los siglos XIV y XV dieron lugar a la existencia de una baja densidad demográfica en el territorio valenciano durante las postrimerías de la época medieval. Este hecho afectó directamente a la economía del reino, en especial a la de los señores, ya que éstos vieron como la perdida de contingente humano, y por tanto de contribuyentes, repercutió negativamente en sus ingresos. Como consecuencia de ello se produjo una revalorización de la mano de obra no solo desde su vertiente productiva sino también fiscal.

\footnotetext{
${ }^{21}$ Muchos de los conflictos nobiliarios se extienden a lo largo del tiempo teniendo puntos de máxima rivalidad en determinados momentos, tal y como se puede observar en el artículo de DIAGO HERNANDO, M., «Las luchas de bandos nobiliarios como factor determinante del conflicto comunero en Plasencia (1520-1522)» en Cuadernos de Historia Moderna, n ${ }^{\circ}$ 31, Madrid, 2006, pp. 63-89.

${ }^{22}$ Tomamos esta clasificación con cierta prudencia pues la casuística es muy amplia y las propias cuestiones de honor, inquinas y odios atávicos entre nobles pueden ser inclasificables. LÓPEZ RODRÍGUEZ, C., Nobleza y poder político..., pp. 155-189.
} 
Ante tal situación los señores se esforzaron por mantener el control de sus vasallos, por fijarlos al territorio, tratando de evitar por diversas vías que éstos emigrasen a otros lugares, al tiempo que intentaban atraer a nuevos pobladores a sus dominios. Esto produjo evidentemente conflictos entre los señores, pues la atracción de nuevos vecinos no responde a un exceso poblacional o a una supuesta afluencia de contingentes provenientes de fuera del reino, sino que se ejerció sobre los habitantes de los lugares cercanos.

En este contexto se ha de subrayar el caso de la población mudéjar. Parece ser que las condiciones del musulmán encuadrado en las tierras señoriales valencianas fueron endureciéndose durante los siglos XIV y XV y que además la lucha de los señores por conservar o atraer esta mano de obra, propició las consecuencias no deseadas por estos mismos. Los ejemplos de permutas de musulmanes de unos señoríos a otros durante el Cuatrocientos fueron muy numerosos. La salida legal, o no, a Granada, Berbería o Castilla en estas décadas ha sido destacada por varios autores, quienes no han dudado de calificarlas como huida en masa, tal y como apunta M. Meyerson ${ }^{23}$. Los campesinos musulmanes supieron aprovecharse de las tensiones señoriales, conscientes de la revalorización de su mano de obra, y por ello se marchaban a otras tierras donde la presión feudal, entendiendo las tasas impositivas y jurisdiccionales, era menor, en busca de condiciones más ventajosas y aprovecharse de legislación más favorable. Pero no únicamente el factor económico estaba detrás de estos movimientos poblacionales, en ocasiones los conflictos internos de las aljamas o el deseo de pertenecer a una comunidad donde se vivía con una mayor libertad religiosa o cultural eran motivos suficientes para mudar su domicilio a otra localidad ${ }^{24}$. Los señores, siempre enfrentados, reaccionaron ante esto de la forma más virulenta y con afán e insistencia desmedida: amenazas, acusaciones criminales infundadas, detenciones cuando los musulmanes querían marcharse a otro lugar, negación de los dominadores cuando querían sus súbditos liquidar cuentas; todo ello con el propósito de retenerlos en sus dominios. Y para captar individuos se levantaban

${ }^{23}$ MEYERSON, M., «Un reino en contradicciones: Valencia, 1391-1526», en Revista d'Història Medieval. Los mudéjares valencianos y peninsulares, 12, Valencia (2001-2002), pp. 24-26

${ }^{24}$ Sobre la movilidad de la población mudéjar en el sur del País Valenciano en el siglo XV: SALICRU i LLUCH, R., «Sarraïns desaveïnats d'Elx a mitjan segle XV (1449) segons llur propi testimoni: dificultats econòmiques i conflictivitat interna de la morería» en Sharq alAndalus, 12, Teruel-Alicante, 1995, pp.23-66. FERRER i MALLOL, M. T. «Lalfaquí Mahomat Alaig i la lluita pel poder a la morería d'Elx (1448-1457) en Revista d'Historia Medieval. Los mudéjares valencianos y peninsulares, 12, Valencia (2001-2002), pp. 185-240. PONSODA LOPEZ DE ATALAYA, S., «Migracions mudèjars i disputes senyorials al sud valencià a les acaballes de l'edat mitjana», en Anales de la Universidad de Alicante. Historia Medieval, 17, 2011 , en prensa. 
peticiones al monarca de rebajar condenas, robo de vasallos a señores legítimos en los caminos, se proporcionaba refugio para esconderse y desvincularse de su señor, se les aceptaba sin haber llegado a cómputo con sus antiguos señores. En medio e intencionadamente se situaba el rey que gracias a los recursos que le permitía la ley y a una red de oficiales, establecía medidas para atraer de los lugares de señorío al realengo ${ }^{25}$.

\section{2. Conflictos por la herencia, el patrimonio y las jurisdicciones señoriales}

En segundo lugar hallamos los conflictos por la herencia, el patrimonio y las jurisdicciones. En este sentido estas rivalidades eran casi inherentes por la propia idiosincrasia de esta clase o grupo político. Existían todo una serie elementos que las propiciaban: las superposición de derechos y dominios del feudalismo, la bilateralidad característica de la parentela cogniticia del mundo latino, la conservación de leyes hereditarias muy complejas y la alta mortandad del modelo demográfico bajomedieval ${ }^{26}$; lo cual facilitó la confusión de los derechos de los individuos sobre el patrimonio familiar. A todo ello habría que añadir las estrategias matrimoniales de cada estirpe, en lo que a su vez se une el carácter endogámico de la aristocracia, la nobleza de mayor poder cuyos enfrentamientos eran los que podían desestabilizar la situación política de los reinos. Esta era una situación más que común en la baja Edad Media y que salpicó a las casas reales sobre todo en coyunturas inestables o de crisis $^{27}$.

Las familias nobles se jugaban en muchos casos su supervivencia en los matrimonios, unión que en los siglos medievales se consideraba como una alianza patrimonial. Es así que cuando fallecía uno de los cónyuges, cosa nada casual, se encendían de nuevo la llama del conflicto, es decir, la incesante lucha por la herencia

${ }^{25}$ Los ejemplos de moros de la Marina que a petición del baile solicitan dejar a sus señores para ser vasallos del Rey, son muestra de esta estrategia; así como la política de atracción y revitalización demográfica de las morerías, los ejemplos también de Orihuela, Castellón son más que evidentes. Sobre este último aspecto ver: NIETO FERNANDEZ, A., «La morería de Orihuela en el siglo XV» en Primer Congreso de Historia del País Valenciano, vol. II, Valencia, 1980, pp. 761-771. BARRIO BARRIO, J. A., «La difícil convivencia entre cristianos y musulmanes en un territorio fronterizo: La gobernación de Orihuela en el siglo XV» en Sharq al-Andalus, 13, Teruel-Alicante, 1996, pp. 9-26. DÍAZ DE RÁBAGO HERNÁNDEZ, C., La morería de Castelló de la Plana 1462-1527: estudio socio-económico de una aljama musulmana medieval, Castellón, 1994.

${ }^{26}$ A causa de la mezcla de elemento agnaticios y cognaticios en la familia noble bajomedieval. LÓPEZ RODRÍGUEZ, C., Nobleza y poder político..., pp. 170-172.

${ }^{27}$ De las minoridades, las guerras privadas, las largas disputas y secuestros judiciales, sacaban provecho los vasallos, debido a las pérdidas de derechos señoriales, la proliferación del fraude y la evasión fiscal.. Ídem, pp. 170-171. 
o por la tutoría de los herederos. A veces estas herencias, si eran cantidades en metálico, podrían solventar las haciendas nobiliarias que por su mengua en los ingresos ordinarios, el nivel de vida de sus titulares y los conflictos con sus homónimos, estaban casi siempre en situación delicada. Lo cual nos ayuda a ver que las familias nobles, como unidades digamos autónomas, eran muy inestables. La solución que se buscó era cambiar las fórmulas testamentarias en la división de las herencias, no vincular todo el patrimonio al primogénito y si a diversas ramas familiares.

Junto a las herencias y sucesiones, los pleitos entre señores que podrían desembocar en guerras abiertas afectaban a todo lo que se relaciona con la compleja propiedad feudal: es decir, divisiones de términos, aprovechamiento de tierras incultas, bosques y pastos, cobro de derechos e impuestos de todo tipo (explotación de hornos, molinos...), propiedad de bienes muebles e inmuebles y fundamentalmente el ejercicio de la jurisdicción señorial.

\section{3. La defensa del honor}

En tercer lugar encontramos la defensa del honor. En todos los conflictos nobiliarios se implicaba de una forma u otra el honor individual y familiar. Este honor, este valor con el que más y mejor se identifican estos individuos, lejos de estar provocado por un irracionalismo ciego, como podríamos pensar en parámetros actuales, estaba relacionado con el deseo de mantener un status social. De hecho en las Partidas se estima que en caso de pérdida de la honra se podría prescindir de la condición de caballero.

En el código medieval clásico, los elementos morales y políticos forman un todo indisoluble, por tanto los conceptos de venganza y «el valer más» estaban a la orden del día y por supuesto sólo se conseguían con el uso de las armas. Es así que el honor además de una virtud era sin duda una apariencia externa que se manifestaba en las armas, el caballo, en el vivir conforme a los usos y costumbres, no realizar ningún trabajo manual, ni practicar el comercio; normas que se consideraban de grupo o de clase al no existir, además, ninguna reglamentación legal. Los medios para mostrar y defender estos valores eran por supuesto las campañas militares $^{28}$, así como la defensa a ultranza del prestigio de la familia, sobre todo cuando afectan al terreno sexual ${ }^{29}$. La exacerbación física y simbólica de estas actitudes queda manifiesta en el imaginario medieval, en la documen-

${ }^{28}$ SAIZ SERRANO, J., Caballeros del rey: nobleza y guerra en el reinado..., donde se insiste en al función social de la nobleza.

${ }^{29} \mathrm{Al}$ ser la honra del sexo femenino cosa tan apreciada por las familias, la demostración del «valer más» (concepto al cual de vincula el honor) en el terreno sexual constituía un señalado triunfo (y, correlativamente, una grave afrenta para la otra parte). Palabras tomadas de J. Caro Baroja. LÓPEZ RODRÍGUEZ, C., Nobleza y poder político..., p. 189. 
tación que analizamos y sobre todo en algunos clásicos de nuestra literatura: podríamos seleccionar múltiples episodios del Tirant lo Blanch ${ }^{30}$.

Pues bien, desde el siglo XIV, tenemos muchas noticias de enfrentamientos entre nobles en el reino de Valencia, circunstancia que se multiplica para el siglo posterior $^{31}$. Los datos son abrumadores y una relación detallada les provocaría cierta inquietud aunque seguro que también aburrimiento: los Moncada y sus aliados pleiteaban contra los Boil y los suyos, o posteriormente frente a los BoílLladró y luego ante los Centelles. Asimismo de nuevo los Boíl-Lladró contra los Maça de Liçana durante largo tiempo; los Pardo de Lacasta en diferentes momentos se oponen a otros nobles de menor rango y, como no, las diversas ramas de los Vilaragut entre ellos mismos y contra todos ${ }^{32}$.

En cuanto a las tierras de la Gobernación de Orihuela, las disputas son también más que frecuentes, como ha recogido el profesor Hinojosa recientemente, como por ejemplo la acaecida entre los Rocamoras y Rocafulls con sus diversas ramas y clientelas oriolanas, sobre la que insistiremos a continuación ${ }^{33}$.

Más que focalizar en una descripción continuada y hasta un punto superfluo de estos acontecimientos que no nos ayudarían a ver la problemática en profundidad, nos centraremos en dos casos específicos, de los dos observatorios donde la señorialización fue un todo en el siglo XV en el mediodía valenciano, el valle de Elda y la vega baja del Segura. Dos espacios que nos sirven para incidir en todo el proceso de lucha y desgate nobiliario y el fortalecimiento del aparato estatal. Hablamos de procesos diferentes en el tiempo, lugar y significado, en tanto en cuanto el primero se desarrolla en un medio rural, donde las disputas entre las dos familias nobles del lugar, Maça de Liçana y Roiç de Corella, serán constantes en una dinámica que también está caracterizada por el uso y abuso de los miembros de este linaje de su posición y resortes de poder al ocupar cargos gubernativos regios. El segundo caso, se sitúa en un medio urbano, donde la nobleza no puede acceder a los cargos en la institución urbana, el consell de

${ }^{30}$ Por citar algunos de los capítulos en los que se muestran claramente diversos aspectos de la mentalidad caballeresca: Capitulo XXXI «Com Tirant pregà a l'ermità que li volgués dir quina cosa era l'orde de cavalleria» o el capitulo LXXV «Com un cavaller nomenat Vilafermosa requerí de batalla a Tirant», en MARTORELL, J. Tirant lo Blanc, edición de RIQUER, M. de, Castelló, 1990.

31 En referencia a los conflictos en el sur valenciano a comienzos del siglo XIV, ver FERRER i MALLOL, M. T. «Discòrdies entre la petita noblesa urbana i els homes de vila a les terres meridionals en el primer terç del segle XIV» en Anuario de Estudios Medievales, 29, Barcelona, 1999, pp. 301-314.

32 Analizados en profundidad en LÓPEZ RODRÍGUEZ, C. «Guerras privadas nobiliarias..., op. cit.

${ }^{33}$ HINOJOSA MONTALVO, J., «Bandos i bandositats en la gobernación de Orihuela en la Baja Edad Media», en Anuario de Estudios Medievales, 36/2, Barcelona, 2006, pp. 713-750. 
Orihuela, pero sí determinar las decisiones de los diferentes actores políticos generando un conflicto endémico, por el tono de enfrentamiento entre estos bandos y allegados, y definitorio de la vida política de este espacio urbano. Por tanto, dos observatorios que radiografían en profundidad las esencias de los conflictos entre nobles en un territorio, donde quizás se agraven y tomen más fuerza las cuestiones de movilidad de la población musulmana y las violencias étnicas, intergrupales e institucionales por el carácter fronterizo del mismo.

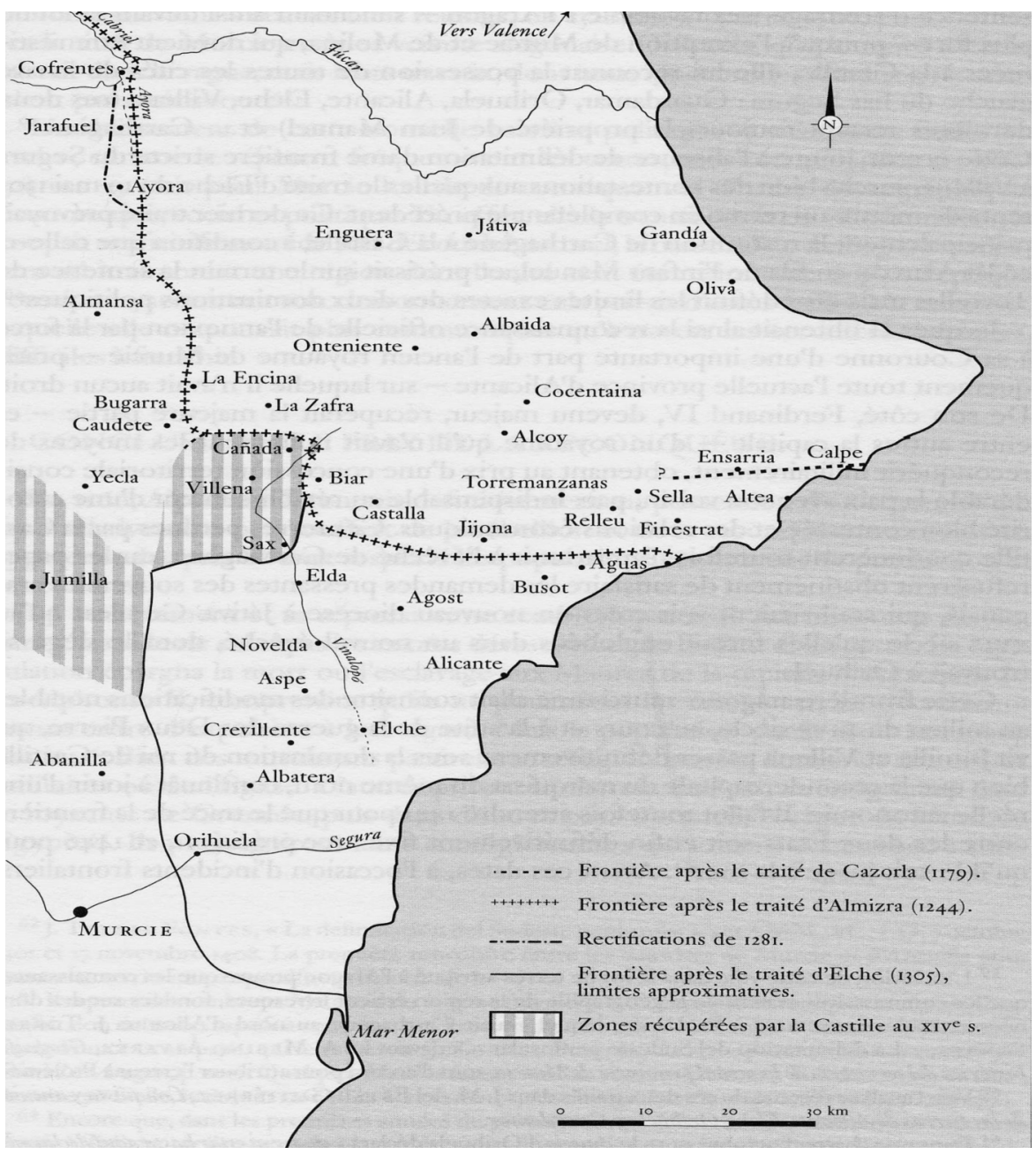

Mapa Frontera del sureste peninsular. Fuente: MENJOT, D., Murcie Castillaine. Une ville au temps de la frontière. (1243-Milieu du XVe siècle).

Vol. I, Madrid, 2002 


\section{UN EJEMPLO DE VIOLENCIA NOBILIARIA EN EL SUR DEL REINO DE VALENCIA: LOS ENFRENTAMIENTOS ENTRE LOS MAÇA DE LIÇANA Y ROIÇ DE CORELLA EN EL VALLE DE ELDA DURANTE LOS AÑOS 1427-1428}

Llegados a este punto y para tratar de ejemplificar las ideas articuladas más arriba, tomamos con observatorio el valle de Elda, tierras meridionales del reino de Valencia, y la disputa de las dos grandes familias nobiliarias que dominaban estas aljamas y villas rurales valencianas. Para ello contamos con un extraordinario proceso que sirve como marco y espejo de parte de vida cotidiana de estas comarcas en su otoño medieval ${ }^{34}$. El proceso analizado en cuestión es la base fundamental de un trabajo actualmente en preparación ${ }^{35}$. Documentalmente este material supera con creces el dato puntual y parcial de la queja o petición de una autoridad ante el baile u oficial pertinente por un hecho de bandositat, como se manifiesta en muchos textos, o por un ataque entre señores de un lugar a otro sin a veces incidir en una causa. Se trata de un proceso que se compone de 148 folios (recto y verso), cuya trascripción, edición y examen revela en toda su complejidad un ejemplo integro y total de violencia nobiliaria ${ }^{36}$.

El valle de Elda, integrado por Novelda, Aspe y Elda como núcleos más importantes, fue durante los siglos bajomedievales un lugar poblado eminentemente por musulmanes. Junto a sus castillos algunos levantados de manera imponente sobre prominentes cerros, se alzaban los minaretes de las mezquitas

\footnotetext{
${ }^{34}$ Archivo del Reino de Valencia (A.R.V.) Bailía. Apéndice. Libro no 83. Este proceso no es inédito, ni es la primera vez que se trabaja. Jaime Richard realizó una primer aproximación en J. RICHART GOMÀ, «Conflictos jurisdiccionales en la villa de Elda entre Pere Maça de Liçana y Ximén Pérez de Corella en 1427», en Revista del Vinalopó, 8, 2005, Novelda-Petrer, pp. 89-96. Sin embargo, por el tratamiento metodológico, la interpretación histórica empleada y la ausencia de inserción y comparación historiográfica, en nuestra opinión necesitaría ser investigado, analizado de nuevo y sobre todo editado.

${ }^{35}$ Por ello en este trabajo simplemente solo presentamos este caso de violencia nobiliaria en un contexto histórico y bajo un modelo metodológico y analítico expuesto y no nos remitiremos a declaraciones específicas, ni menciones archivísticas concretas, que si se recogen detalladamente en SOLER MILLA, J. L., URZAINQUI SÁNCHEZ, S., Violencia nobliaria y conflicto jurisdiccional en las tierras meridionales del reino de Valencia (siglo XV), en prensa.

${ }^{36}$ No podemos resistirnos a comentar la relevancia de los datos históricos, realidades, comentarios que emanan estos documentos para el valle de Elda; en si se trata de un complejo fresco que esboza múltiples imágenes sobre la vida cotidiana del lugar: los gestos, las actitudes, las costumbres, el silencioso trabajo en la huerta hasta la antroponimia de sus vecinos; en fin, sus sin sabores y actividades se personalizan bajo las letras e imágenes de esta documentación.
} 
que jalonaban estas tierras bajo la silenciosa cotidianeidad del trabajo doméstico y agrícola rutinario de sus habitantes. Por su idiosincrasia y tonalidad social, por el eco de los escasos testimonios que se conservan, por el silencio vertido por parte los historiadores de éstas y otras comarcas rurales valencianas, su realidad e imagen histórica no nos puede dejar de evocar la misma sensación que la vall de les sis mesquites, parafraseando otro extraodinario libro ${ }^{37}$.

Quizás estas aljamas, estas comunidades locales presentaron alguna especificidad que venía propiciada por la existencia y riqueza de productos (como uvas pasas, azafrán, comino...) anhelados por mercaderes valencianos, mallorquines y extranjeros (franceses, italianos...) para insertarlos en los mercados mediterráneos y atlánticos a través de los puertos de Alicante y el Cap de l'Aljub ${ }^{38}$. Además, como buena parte de la gobernación de Orihuela, estas comarcas conocieron un carácter fronterizo más que complejo. Enclavadas en el límite del país, lindando con el marquesado de Villena, el reino de Murcia y, aunque hoy nos pueda parece extraño por la lejanía física, con el sultanato nazarí de Granada. Frontera terrestre y frontera marítima. Lugar de destacables rentas pero territorio fácilmente franqueable desde uno y otro frente, penetrable en razzias por almogávares granadinos y crisol de intercambios culturales y económicos. Marco incomparable para la conflictividad política, la inseguridad social y también el negocio en su mayor sentido. Espacio en continua estructuración y desestructuración ${ }^{39}$.

${ }^{37}$ GARCÍA-OLIVER, F., La vall de les sis mesquites. Valencia. 2003, Ídem, «Un valle musulmán junto al mar», en PIQUERAS SÁNCHEZ, N. (Coord.) Entre tierra y fe: los musulmanes en el reino cristiano de Valencia (1238-1609) Valencia, 2009, pp. 375-382.

${ }^{38}$ Las cuestiones económicas, atendiendo al ámbito mercantil en SOLER MILLA, J. L., «Tonalidad económica y especulación mercantil en las aljamas valencianas medievales. Las comarcas rurales meridionales (siglo XV)», en Medievalismo. Boletín de la Sociedad Española de Estudios Medievales, 2007, pp. 215-245; respecto a la fiscalidad: BARRIO BARRIO, J. A. y CABEZUELO PLIEGO, J. V., «Rentas y derechos señoriales de las morerías del valle de Elda a finales del siglo XV», en VII Simposio Internacional de Mudejarismo. Teruel, 1999, p. 43-53. La realidad productiva de estas aljamas esta determinada por su actividad fundamentalmente agrícola dominada por los cereales (trigo, cebada, alcandia, panizo, centeno), las leguminosas (destacando las habas), los olivos para la producción de aceite destinada al autoconsumo, los almendros destinados claramente a la comercialización, el azafrán y el azafrán borde -alasfor- con el mismo criterio que los últimos, además de la viña que ocupa y concentra la mayor parte de estas tierras, destinadas a la elaboración de la uva. FERRER i MALLOL, Ma. T., Les aljames sarraines a la Governació d'Oriola en el segle XIV,Barcelona, 1988, pp. 47-50.

${ }^{39}$ La variable fronteriza de estas tierras es ampliamente tratada y relativamente bien conocida: FERRER I MALLOL, M. ${ }^{a}$. T., La frontera amb l'Islam en el segle XIV. Cristians i sarraïns al Pais Valencià. Barcelona, 1988; Ídem, Organització i defensa d’un territori fronterer. La Governació d'Oriola en el segle XIV. Barcelona, 1990. De forma conjunta con una enfoque exclusivamente económico CABEZUELO PLIEGO, J.V. y SOLER MILLA., J. L., «Por aquella tierra que esta en medio. Violencia y negocio en la frontera meridional valenciana durante 
En el momento que nos hallamos, 1427, después de conocer variaciones seculares en sus dominios jurisdiccionales, estos valles quedaron encuadrados en el marco de la jurisdicción señorial ${ }^{40}$. Fundamentalmente dos familias que mantuvieron un enfrentamiento constante utilizando sus alianzas con otros nobles y sus cambiantes relaciones con el poder real ${ }^{41}$, esto es, los Maça de Liçana y los Roiç de Corella. Los primeros, los Maça de Liçana, constituían una familia de la alta nobleza, eran de los pocos barones que remontaban su origen a linajes de la alta aristocracia aragonesa o catalana de la más rancia estirpe, que se habían instalado en Valencia a lo largo del Doscientos. Dentro de este grupo estaban los Cardona y por supuesto la nobleza de sangre, además de los Centelles, Próxita, Vilaragut y, claro, los Maça. En este caso, el personaje a analizar, Pero Maça poseía Novelda y otros lugares menores como Monóvar y el castillo de la Mola, La Romana, Pinoso, ubicados todos ellos en las comarcas rurales más meridionales del territorio valenciano a través de una concesión regia de Juan I en 1393, que se añadía a su anterior territorio señorial matriz, Moixent, y otros lugares en suelo valenciano como Alberic, la Foia, Benifaraig y Rafalet ${ }^{42}$. Los Roiç de Corella, al contrario que sus enemigos acérrimos, no tenían un pasado tan esplendoroso, pero mediante diferentes estrategias, como hicieron muchos nobles durante la baja Edad Media, a través de servicios militares y favores al monarca, ascendieron a tal categoría. Esta familia gozó del favor regio tras la campaña de la Corona de Aragón en Nápoles (antes en Marsella y Cerdeña) otorgándoles el rango de condes desde 1448. De esta forma Ximen Pérez de Corella se intitulaba conde de Cocentaina, marco señorial que englobaba además de esta villa y dominio del

el primer tercio del siglo XIV», en VI Encuentros de Estudios de Frontera, Homenaje al prof. Manuel González Jiménez, Alcalá La Real (Jaén), 2007, pp. 133-150. ORTUÑO MOLINA, J., SOLER MILLA, J. L., «Espacio jurisdiccional y espacio económico en el Sureste Peninsular en la Baja Edad Media», Journal of Medieval Iberian Studies, 1:1, Michigan-EE.UU., 2009 , pp. $69-85$.

40 Sobre los cambios en la titularidad de estos señoríso a lo largo de los siglos bajomedievales ver: FERRER i MALLOL, M. T., Les aljames sarraïnes de la Governació d'Oriola...pp. 3-43, y PONSODA LÓPEZ DE ATALAYA, S., «Movilidad y permanencia en la titularidad de los dominios señoriales de la gobernación de Orihuela a finales de la Edad Media» en Miscelánea medieval murciana, en prensa.

${ }^{41}$ El enfrenamiento nobiliar, Maça de Liçana versus Roiç de Corella, ha sido analizado en detalle en SOLER MILLA J. L., URZAINQUI, S., Violencia nobiliaria y conflicto jurisdiccional en la frontera sur valenciana..., op. cit. En cuanto a los múltiples conflictos de los Maça de Liçana, dependiendo de su liderazgo de los partidos nobles políticos, los enfrentamientos entre estos últimos o con la monarquía: LÓPEZ RODRÍGUEZ, C., «Guerras privadas nobiliarias y paz pública...»

${ }^{42}$ LÓPEZ RODRÍGUEZ, C., Nobleza y poder político..., nota 148. De la historiografía local véase SALA CANELLAS, V., Novelda en el ayer. Novelda. 1979; ABAD NAVARRO, E., El castillo de la Mola de la ciudad de Novelda. Alicante. 1984. 
Alcoià-Comtat -desde 1448-, sus posesiones de Aspe, Elda y Petrer, además de Salinas, adquiridas a la reina Violante en $1424^{43}$. Así pues, nos encontramos ante nobles que ocuparon cargos políticos de confianza siendo coperos, virreyes, gobernadores, diplomáticos y estrategas militares, los Roiç de Corella, y, asimismo, mayordomos, capitanes generales, líderes de partidos políticos nobiliarios, capitanes generales y gobernadores de las tierras oriolanas, los Maça de Liçana ${ }^{44}$.

Ambas familias se insertan dentro del marco nobiliario de las tierras meridionales valencianas, más concretamente la gobernación de Orihuela, donde al parecer la nobleza no tuvo ni la fuerza ni el desarrollo como en otros espacios señoriales más arriba de la línea geográfica, Biar-Bussot, configurada en los tratados entre los dos estados peninsulares durante el Doscientos ${ }^{45}$. Aunque, el reino de Valencia no se puede considerar un territorio que destaque por grandes señoríos o casas señoriales poseedoras de espacios y rentas como en la corona castellana, si que fue, como también se ha destacado, un «pais ple senyors».

Pero Maça de Liçana había partido con su caballo y compañeros, tramando su cabalgada desde Orihuela, probablemente desde los lugares de su señorío a la

${ }^{43}$ Las acciones política principales de este linaje, sobre todo en el ámbito meridional y que siguen siendo básicas para conocer su trayectoria se pueden ver en FERRER I MALLOL, M. T. Les aljames sarraïnes de la governació d'Oriola..., p. 43; POVEDA NAVARRO, A.M., «Villa et castiello de Ella (Elda) en el siglo XIII», en Anales de la Universidad de Alicante. Historia Medieval, 4-5, Alicante, 1985, pp. 67-98; Ídem, «Piezas cerámicas emblemáticas del señorío de los Corella..., pp. 302-309, CABEZUELO PLIEGO, J.V., «Elda Medieval. El dominio cristiano», en VV.AA. Historia de Elda, Vol. I, Elda, 2006, pp. 141-156.

${ }^{44}$ Las líneas generales de estas familias, junto con otros barones valencianos, se puede seguir en LÓPEZ RODRÍGUEZ, C., Nobleza y poder..., pp. 66-72.

${ }^{45}$ La nobleza de la gobernación de Orihuela sigue siendo un tema por abordar desde un amplio estudio archivístico, documental e interpretativo. Las visiones aproximativas, desde el ámbito político y jurisdiccional para los siglos bajomedievales; ALBEROLA ROMÁ A., «Los señorios alfonsinos en el sur de País Valenciano. Aproximación a su estudio», en E. SARASA SÁNCHEZ y E. SERRANO MARTIN (eds.), Señorío y feudalismo en la Península Ibérica (ss. XII-XIX). Vol. III, Zaragoza, 1993, pp. 223-240; BARRIO BARRIO J.A., «El señorío de la Daya y el municipio de Orihuela en el siglo XV», en E. SARASA SÁNCHEZ y E. SERRANO MARTIN (eds.), Señorío y feudalismo en la Península Ibérica (ss. XII-XIX). Vol. III, Zaragoza, 1993, pp. 259-270. BERNABÉ GIL D., «Sobre el origen territorial en los señoríos valencianos de colonización alfonsina», en E. SARASA SÁNCHEZ y E. SERRANO MARTIN (eds.), Señorío y feudalismo en la Península Ibérica (ss. XII-XIX). Vol. III, Zaragoza, 1993, pp. 123-138. 
vecina Elda, las tierras integradas por Novelda, Monovar y Chinorla, uno de los de territorios matrices de señorío, junto a la villa de Moixent. Su actitud e intención política y oficial, Pero Maça de Liçana, actuaba como gobernador de los tierras oriolanas, seguro que agraviada por las rencillas personales, intereses y disputas contra su contrario, Ximen Perez de Corella, no era otra que nominalmente capturar y someter a justicia a Çintar.

¿Quién era este Çintar?. Este individuo había sido acusado de crim de collera o plagii, es decir, un collerat ${ }^{46}$ : un individuo que se dedicaba a crear inseguridad y desorden en estos valles traficando en amplio sentido en la frontera con esclavos, ganado, productos para revenderlos. Contaba, Çintar, con el respaldo de sus correligionarios, no sólo a priori los musulmanes. Sus compañeros y amigos los eran todos por igual, tanto los cristianos como los mudéjares sin entender de escalafón social y político: alcaide, hostaler, labradores de la cruz pero también cadí, alfaquí y campesinos de la media luna. No en vano este Çintar era también conocido como Johan de Molina ${ }^{47}$. Su persona constituía las dos caras de la moneda, cristiano y musulmán, como confiesan testigos de uno y otro lado; su profesión religiosa podía ser y era cambiante como su afán económico y suerte, casos similares podemos encontrar para las mismas tierras ${ }^{48}$, cuya razón de ser en la permeabilidad ligüística, social y cultural.

Refleja perfectamente un ideal de hombre de frontera, como ha establecido la profesora Ferrer i Mallol, «de una frontera per a gent que no desitjava una vida de treball tranquil-la, sense sobresalts, era des de sempre refugi d'aventurers, de gent que sentia gust per la vida arriscada i que vivia dels colps de mà i del saqueig sobre terra enemiga $\star^{49}$.

\footnotetext{
${ }^{46}$ Como señala $\mathrm{M}^{a}$. T. Ferrer i Mallol «El collerat era l'individu que formava part d'una banda o societat per a fer saltejaments i especialmente per captivar gent lliure». FERRER i MALLOL., $\mathrm{M}^{\mathrm{a}}$. T., La frontera amb el Islam..., p. 50 y para ver toda la casuística en la frontera meridional valenciana teñida por la idiosincrasia bélica de las gentes, el funcionamiento de estas bandas, los castigos, las persecuciones y la legislación contra los «collertas», pp. 47-72.

${ }^{47}$ La dedicación a tales actividades o profesión de Çintar, más allá de cualquier duda o interpretación siguiendo el proceso, no ha lugar a dudas. De hecho en otro pequeño proceso de una denuncia del procurador del baile de Xàtiva por un ataque de almogávares granadinos y musulmanes valencianos (sobre todo de Anna) a la huerta setabense, de la larga lista de individuos acusados de collerats y plagiariis, procedente del marquesado de Villena, Murcia y la bailía deçà ey dellá Xixona, figuraba Johan de Molina. SOLER MILLA, J. L., «Sobre almogávares, razzias y frontera. El ataque a la Huerta de Xàtiva en 1427», en prensa.

${ }^{48}$ CABEZUelo PlieGO, J.V., «Cristiano de Alá, renegado de Cristo: el caso de Abdalla, fill d'En Domingo Vallés, un valenciano al servicio del Islam», en Sharq al.Andalus, 13, 1996, Teruel-Alicante, pp. 27-46. Otros en FERRER i MALLOL., Ma . T., La frontera amb el Islam..., p. 50-58. Para tratar la cuestión de los renegados muy interesante; BENASSAR, B., BENNASSAR, L., Los cristianos de Alá. La fascinante aventura de los renegados. Madrid. 1989.

${ }^{49}$ FERRER i MALLOL, M. T., La frontera amb el Islam..., pp. 47-48.
} 
Su llegada a Elda, nos referimos al gobernador Pero Maça, fue más que tumultuosa, aquel martes 18 de noviembre de 1427 «en ora de vespres», en el valle recorría un viento de rebeldía. Pero Maça se dirigió al castillo donde quería tomar a su presa, en su cabalgada le acompañaban el noble Pere Rocafull, Luis de Galbe, y algún escudero, quienes con sus caballos y lanzas alzadas sembraron el temor de la escasa población que rondaba la plaza de esta pequeña villa. Ésta quedaba salpicada por un, se lee en el documento, «hoy crits de via fora», dice un tesitgo, «que cridaven les mores de la dita vila vers la plaça»; -incluso una, del temor, murió abortando su criatura-. Antes del llegar a la torre, la comitiva de Maça había atacado con «les spases treytes» las casas de dos musulmanes, Çacim Cancha y Moçamach, donde solía comer Çintar; una vez en la fortaleza eldense amenazaban a su alcaide, Joan de Caravall, haciéndole saber que arribaban aquí para tomar un enemigo del Rey, que debía entregar, a Çintar. Éste ya no se encontraba en la villa aunque curiosamente horas antes estaba en el hostal de Ferrando Alfonso, donde había bebido y comido convidado por compañeros y amigos castellanos de Mula y el alcaide de la vecina Sax. Caravall se resistía una y otra vez y manifestaba ver las provisiones del monarca, aunque decía no poder darle a Çintar ya que no lo tenía en su poder. Además, el alcaide alzaba la voz recordándole en buen grado que ellos sólo eran vasallos del señor mossen Corella. Mientras los hombres del gobernador Pero Maça seguían recorriendo la villa y las diferentes casas causando malestar y daño.

El resto de la comunidad, los campesimos musulmanes, como no podría ser de otra forma, se hallaban en la huerta; no era un día normal para ellos. La voz y gritos de la mujer del alcaide del castillo les advertían del tumulto, los musulmanes del lugar ascendieron a la fortaleza, se enfundaron sus más que modestas armas (lanzas, ballestas y seguro que dagas y piedras) para defender su plaza o simplemente para protegerse. Finalmente, ante la modesta revuelta o la defensa local, Pero Maça tuvo que huir, aconsejado por el notario de la villa eldense, Granyana, sufriendo seguramente más de lo que se esperaba: perdía su paje y dos caballos; y seguro que menos de los que sus enemigos pretendían. Además, el gobernador gritaba enfurecido lo que consideraba una resistencia desleal. De hecho en sus declaraciones manifestaba la resistencia prestada por los moros quienes a una pregunta suya, no sabemos si certera o no, decía así «ino conexeu que yo son vostre governador»? A lo que le espetaban la siguiente respuesta: «no conexen governador ni Rey sino a mossén Corella». Transcurridos dos días, un hombre al servicio de Pere Maça denunciaba tales cosas y demandaba una plena recomposición, siendo plenamente no correspondido. El gobernador hundido en su honor y colmado por la ira, en la cabeza le rondaba la mayor venganza: convocar huestes y volver para infringir daño. Lo llevaría a cabo en un tiempo, lo describiremos posteriormente. 
Sin embargo ¿qué se puede vislumbrar del comportamiento de los vasallos musulmanes? Es difícil conocer muchas veces sus comportamientos sociales. Puede resultar paradójico la defensa que hacen de su señor, no pasemos por alto la condición cristiana y sobre todo no olvidemos la punción fiscal a la que los sometía regularmente. Pero el comportamiento del Maça de Liçana les parecía una injerencia, una ofensa, un desorden. Había tocado a uno de los suyos, a Çintar. La comunidad conocía a Çintar, sabía de sus hechos, éste frecuentaba uno y otro lado de la frontera, vivía y convivía con sus compañeros de fe, y también con sus compañeros de tramas, negocios y violencia, cristianos y musulmanes. ¿Solidaridad de grupo, conveniencia, trama de intereses? Nos resulta muy difícil examinar esta actitud de estos campesinos. Estos sarracenos estaban más que acostumbrados a individuos como Çintar, los aceptaban en el mejor y peor sentido cuando no se beneficiaban de sus hechos. A un lado y otro de la frontera valenciana, se dibujaban varios horizontes para estos musulmanes, el puramente económico, el conocido familiar y el desorden en forma de contrabando en las morerías murcianas y sobre todo en tierras nazaríes. Las conexiones eran extraordinariamente mayores, musulmanes de uno y otro lugar quedaban realmente comunicados e interesados socioeconómicamente. La percepción mental tanto del hombre medieval como fundamentalmente de las autoridades políticas, municipales y reales, estaba dominada por la aceptación, ligazón y unión de las comunidades islámicas de sus entidades jurisdiccionales con otras dentro y fuera de sus reinos. La comunidad era cómplice de este individuo. Incluso su señor, como observamos en este proceso, entiendía y aceptaba a Çintar. Esta actitud podría ser paradójica o perjudicial para sus señores, Ximen Pérez de Corella, pero no era de esta forma. El señor se preocupaba básicamente de que se recolectara, bien los frutos de sus campos, recogieran bien las rentas derivadas de diversos impuestos sancionadas a la comunidad por su trabajo, uso de monopolios o conflictos judiciales. Incluso se ha señalado el desinterés por parte del cuerpo señorial por la actitud socioreligiosa de estas comunidades musulmanes que podrían zaherir no sólo a sus vecinos cristianos como a poner en jaque o peligro una pretendida e inalcanzada estabilidad sociopolítico en territorios fronteros, siempre sacudidos por razzias de uno y otro lugar. Además para Ximen Perez de Corella estos hechos eran uno de tantos para mostrar su dominio y poder, consistía en una verdadera justificación para enfrentarse contra su enemigo. Los campesinos musulmanes respondían solo ante la autoridad y actividad jurisdiccional de su señor. Cualquier otra autoridad, gubernativa, como los Maça (poder del rey), señorial, como los Maça (de sus correligionarios de Novelda, Monovar y Chinorla, musulmanes que están muy relacionados familiar y económicamente), lo ven como una injerencia. El señor protegía la idiosincrasia de la economía 
fronteriza del valle de Elda, comercio, contrabando, almogavaría, negocio, de lo que se aprovecha. El señor respetaba, dejando a un lado o no atiendiendo las prácticas sociales de los musulmanes, más allá del marco de segregación social establecido en todos los órdenes por la legislación política regia. Solo se altera el orden en el ámbito fiscal y las servidumbres, puncionaba a los campesinos cuando podía. Sin embargo, no le interesaba a veces disminuir las conexiones con granadinos, las redes sociales que tejían con otros musulmanes del país de y de fuera y las prácticas religiosas, una imagen semejante a los moriscos de mediados del XVI. Por eso los musulmanes de este lugar solo conocían ese orden sociopolítico, no otros.

Volvamos. En efecto, el 25 de noviembre, sólo una semana después de la primera «venguda», Pero Maça cumplía lo prometido en su deshonrosa desbandada. Regresaba a Elda con una hueste ciertamente importante reclutada en el Fondo, paraje entre Crevillente y Aspe. Talaba y quemaba parte de la huerta: olivos, viñas y otros cultivos, sus soldados acometían el robo de frutos, alasfor, bataflava, comino..., (es muy fácil pensar que pudieron hacer con estos apreciados productos, venderlos con prontitud en las redes económicas fronterizas, tejidas por el contrabando y comercio sumergido ${ }^{50}$ y la captura de al menos 25 musulmanes. En fin, inflingió un castigo premeditado, mayor y fuera de ley, cuanto más violencia y más destrucción, mayor era el daño a su oponente, Ximen Perez, que se quedaba sin su apreciadas rentas y una comunidad desolada, aunque sólo momentáneamente. Acto seguido, a la acción más visceral se unía la más política, oficial e incluso sibilina. Pero Maça convocaba a las autoridades de la aljama; alcadí, çalmedina y miembros de la aljama, haciéndoles jurar por fueros y privilegios y çuna e çara su obediencia y lealtad al Rey que en esos momentos ni más ni menos el mismo representaba. No faltaba ni mucho menos la simbología pertinente: señales reales en los hostales y estandartes regios en las torretes del castillo y minaretes de las mezquitas. Por último, retenía el castillo para si. La imagen era evidente: la vall d’Elda era más real y más ordenada. Más de los Maça de Liçana, menos de los Roiç de Corella.

Desgraciadamente no se conserva el final de proceso, no conocemos la sentencia. A través de varias misivas el Magnánimo obligaba a Pero Maça a que restituyera la fortaleza a Ximen Perez, que no la retuviera por fuerza más tiempo no considerando, por tanto su ocupación violenta y no reconociendo los nombramientos de oficiales que había hecho el Maça para asentar su dominio y otras atribuciones, por

\footnotetext{
${ }^{50}$ Véase una reflexión en MENJOT, D., «Le contrabande dans la marche frontiere murcienne au bas Moyen Âge», en Homenaje al profesor Juan Torres Fontes, vol. II, Murcia, 1987, pp. 1073-1083 ; Idem, MENJOT, D., Murcie Castillaine. Une ville au temps de la frontière. (1243-Milieu du XV siècle). Vol. I, Madrid, 2002, pp. 584-597; y CABEZUELO PLIEGO, J.V., «El negocio del rapto en la frontera de Orihuela a principios del siglo XIV», en Miscelánea Medieval Murciana, Vol. XXI-XXII, Murcia, 1997-1998, pp. 43-58.
} 
tanto toda la situación volvía a sus orígenes de aquel ya lejano otoño de $1427^{51}$. Asimismo, el monarca solicitaba la audiencia de su gobernador por probablemente los desmanes que había realizado fruto de la jurisdicción regia delegada que poseía en el territorio gubernativo oriolano, como en este y probablemente otros casos $^{52}$.

Pero ni unos ni otros se colmaron, ni intervenía por última vez la persona interesada y mano del monarca. Unos meses después o bien pocos años, los hechos se repetían: documentos de la segunda mitad del s. XV aluden de nuevo a disputas, rencillas y odios entre estas dos familias ${ }^{53} \mathrm{o}$ una de ellas con otras instancias oficiales, bien municipales o bien reales ${ }^{54}$. En el caso del Medio Vinalopó, los enfrentamientos señoriales sólo terminarían en el umbral de la Modernidad con la venta de estas comarcas del señorío de los Corella a otra familia nobiliaria, los Coloma, fruto del endeudamiento de la casa señorial y como único solución a su supervivencia. Pero que en otros valles, en otras comarcas de fuerte raigambre señorial, el mismo vall d'Albaida o Cocentaina continuaría durante muchas décadas, eso siempre diferenciadas en su solución por la intervención regia cada vez más férrea y controladora ${ }^{55}$.

\section{LAS BANDOSITATS ENTRE LOS ROCAFULL-ROCAMORA-MASQUEFA EN ORIHUELA}

Junto al caso expuesto anteriormente encontramos en la gobernación oriolana otro ejemplo, para fines de la Edad Media, de un conflicto entre familias nobiliarias. Si bien cabe destacar el hecho que, en la cuestión que desarrollaremos a continuación, el marco en el que se produce dicha disputa es, en contraposición al ya tratado, y como ya hemos señalado anteriormente, el ámbito urbano de la ciudad de Orihuela. Nos encontramos pues ante una muestra más de un fenómeno que se desarrollará en las principales urbes de la Corona de Aragón, así como en otros territorios, durante los siglos XIV-XV, y que está relacionado, según el profesor R. Narbona, al momento en el que las ciudades empiezan a al-

\footnotetext{
${ }^{51}$ A.R.V. Real Cancilleria (R.C.), Registro (reg), 42, ff. 98v-99r.

52 A.R.V. R.C. reg. 43 f. $14 \mathrm{r}-\mathrm{v}$.

${ }^{53}$ Tenemos constancias documentales de estos hechos sólo uno meses después octubre-diciembre de 1428, en 1440. POVEDA NAVARRO, A., «Piezas cerámicas emblemáticas del señorío de los Corella..., pp. 302-309.

${ }^{54}$ FERRER i MALLOL, M. T. «L’alfaquí Mahomat Alaig i la lluita pel poder a la morería d’Elx..., op. cit.; GARRIDO I VALLS, J.D., «Les comunitats musulmanes d'Elx i Crevillent sota la senyoria de Barcelona», en La Rella, 16, Elche. 2003, pp. 11-36; de forma específica como análisis del ataque de los oficiales de los Corella sobre la huerta de Crevillente en 1457; BENÍTEZ BOLORINOS, M., «La familia Corella.1457, un caso de bandolerismo nobiliario», en Anales de la Universidad de Alicante, Historia Medieval, 14, Alicante, 2003-2006, pp. 66-68.

55 S. URZAINQUI SÁNCHEZ, «Luchas nobiliarias por el control de aguas de riego, tierras de cultivo y pastos durante el reinado de Carlos V», en Estudis, n³ 32, Valencia, 2006, pp. 195-225.
} 
canzar un estadio de evolución socio-económica superior ${ }^{56}$. Por tanto observaremos algunas variables diferenciadas del conflicto referido líneas arriba, como por ejemplo la condición socio-política de los principales protagonistas, las familias Rocafull, Rocamora y Masquefa. En este sentido podemos decir que la mayoría de los individuos que se ven involucrados en las disputas, si exceptuamos a los Rocafull, forman parte de la baja nobleza, caballeros y donceles, que nutren a la oligarquía municipal de la localidad y que arrastrarán consigo a otros familiares y amigos, constituyéndose así en verdaderos bandos enfrentados que alterarán la vida cotidiana de la ciudad.

El tema que trataremos a continuación no es inédito, pues el profesor Hinojosa Montalvo ya dio a conocer ampliamente los hechos que se sucedieron en los enfrentamientos que protagonizaron las familias anteriormente citadas durante el último tercio del siglo XV ${ }^{57}$. De este modo, el propósito de este apartado no es el de volver sobre lo ya trabajado, sino que nuevas referencias documentales nos han permitido aproximarnos a otros aspectos como la composición de los bandos y las repercusiones políticas que los acontecimientos tuvieron sobre algunas de las instituciones, tanto reales como municipales.

De entre las diferentes causas desarrolladas en el apartado anterior que se esconden detrás de las banderías nobiliarias, podemos señalar, para el caso que nos ocupa, que el principal factor que desencadenó en primera instancia el enfrentamiento entre los Rocafull y los Rocamora fue el honor. Un sentimiento éste intrínseco al sector nobiliario y que constituye su actitud ante la vida al tiempo que es una manifestación externa de su posición social ${ }^{58}$. Así pues, los nobles trataran de conservar a cualquier precio dicha honra, lo que desembocará a menudo en conflictos armados.

En este sentido, el detonante que precipitó los acontecimientos lo encontramos en la muerte de mosén Antoni Amorós, alcaide de Callosa, y de don Ramón de Rocafull, señor de Asprella, subrogado del gobernador de la partida d'enllà Xixona y primo hermano del señor de Albatera, a manos de Pere, Francesc y Jaume Rocamora. Los fallecidos fueron asaltados cuando se dirigían a Orihuela, a la altura de Elche, donde estaban refugiados los Rocamora a causa de un alter-

\footnotetext{
56 NARBONA, R., «Violencias feudales en la ciudad de Valencia», Revista d'Història Medieval, $\mathrm{n}^{\circ}$ 1, València, 1990, p. 70. DIAGO HERNANDO, M., «La incidencia de los conflictos banderizos en la vida política de las ciudades castellanas a fines de la Edad Media: el caso de Cuenca», en Hispania. Revista española de Historia, vol. 69, 233, Madrid, 2009, pp.683714. QUINTANILLA RASO, M. C. «Política ciudadana y jerarquización del poder. Bandos y parcialidades en Cuenca» en En la España medieval, 20, Madrid, 1997, pp. 219-250.

57 HINOJOSA MONTALVO, J., «Bandos i bandositats en la gobernación de Orihuela, Op. cit.

58 NARBONA., «Violencias feudales..., p. 65.
} 
cado previo sucedido en la capital oriolana ${ }^{59}$. Conocida la noticia en Orihuela los acontecimientos se precipitaron y así, tanto don Ramón de Rocafull, señor de Albatera, como Nofre y Lluís de Rocafull, hermano y primo del fallecido, inician el acoso de los Rocamora que aún quedaban en dicha localidad. Dicha persecución se saldó con la muerte de mosén Jaume Rocamora, cabeza del linaje, y el ataque a la casa de su hermano Joan Rocamora, major, quien logró escapar a Elche, pero no por ello evitar que buena parte de sus bienes cayeran en manos de los Rocafull ${ }^{60}$.

Tras los altercados mencionados, las disputas entre ambos bandos se sucederán en el plano judicial, si bien aún existirán algunos capítulos violentos, hasta que en el verano de 1477 se consigue que ambas partes firmen una tregua ${ }^{61}$. Esta concordia será prorrogada durante los años posteriores, sin embargo su vigencia peligró a mediados de 1479 cuando Jaume Rocamora dio muerte a dos musulmanes vasallos de don Ramón de Rocafull, por lo que el ya rey Fernando II se apresuró a ordenar la prisión del autor de los asesinatos al tiempo que rogaba a los Rocafull que no se tomaran la justicia por su mano ${ }^{62}$.

Más allá de las fricciones y debates judiciales entre los Rocafull y los Rocamora, las secuelas de este clima de inestabilidad y violencia alcanzaron también a otra de las familias más destacadas de la localidad, los Masquefa. En este sentido, ante la situación que se vivía en Orihuela, el monarca Juan II decide nombrar como justicia criminal de la ciudad para el año 1469 al caballero Jaume Masquefa, señor del lugar de La Daya, con el propósito de alcanzar la pacificación de la $z^{2} a^{63}$. Una designación que rápidamente tuvo consecuencias. Por un lado, el mismo Consell oriolano manifestó su desacuerdo ante tal nombramiento alegando en primer lugar que dicha disposición iba contra los privilegios de la ciudad y que la persona elegida formaba, además, parte del bando de los Rocamoras, lo que contribuiría a exacerbar aún más los ánimos de parte de los contendientes. Tal desacuerdo llegó incluso a provocar que las autoridades municipales negaran

${ }^{59}$ HINOJOSA MONTALVO, J., «Bandos i bandositats en la gobernación de Orihuela..., pp. 734-735. BELLOT, mossen Pedro: Anales de Orihuela (siglos XIV-XVI), vol. II, TORRES FONTES, J. (ed.), Murcia, 2001, p.113.

${ }^{60}$ A.R.V., Real Cancillería (R. C.), reg. 291, ff. 121v-122v (Zaragoza, 5, mayo, 1469). En dicho documento se recogen buena parte de los bienes confiscados por los Rocafull a Joan Rocamora.

${ }^{61}$ A.R.V. R.C. reg. 114, ff. 112r-113r (Barcelona, 9, septiembre, 1478) en HINOJOSA MONTALVO, J., HINOJOSA MONTALVO, J., «Bandos i bandositats en la gobernación de Orihuela..., p. 738.

${ }^{62}$ Archivo de la Corona de Aragón (A.C.A), Real Chancillería (R.C.), Registro (Reg) 3605, ff. 31r-v (Zaragoza, 8, julio, 1479).

${ }^{63}$ A.R.V. R.C. reg. 292, ff. 64v-65r (Zaragoza, 18, enero, 1469) en HINOJOSA MONTALVO, J., «Bandos i bandositats en la gobernación de Orihuela..., p. 736. 
la entrada a Jaume Masquefa a Orihuela para poder ejercer su cargo, por lo que éste se vio obligado a recurrir al rey para hacer efectivo el nombramiento ${ }^{64}$.

Por su parte los Rocafull tampoco aceptaron de buen grado la imposición de Jaume Masquefa y así poco tiempo después, y bajo el pretexto de ir contra algunos hombres de los Rocamora, atacan el lugar de La Daya junto a miembros de su parcialidad como Martí Maça, hermano del gobernador don Pero Maça ${ }^{65}$. Este hecho supuso que tanto Ramon, como Nofré i Lluís Rocafull abandonaran la gobernación oriolana, lo que no evitó que fueran sentenciados a muerte mediante un proceso de ausencia, instando el mismo monarca al gobernador y a sus oficiales a que apresaran a dichos individuos si volvían a los territorios bajo su jurisdicción ${ }^{66}$.

Pero se ha de señalar que dicha sentencia parece ser que no fue ejecutada pues años más tarde encontramos noticias de otro enfrentamiento entre los Rocafull y los Masquefa. A inicios de la última década del siglo XV Damiata de Rocafull y sus hijos Ramon y Lluís, así como sus escuderos y un mozo y un esclavo del último, fueron denunciados por la muerte de Perot Masquefa, hijo de Jaume Masquefa, y por las heridas perpetradas a su mujer y a su sirvienta ${ }^{67}$. De nuevo fue pronunciada otra sentencia de muerte contra los Rocafull ${ }^{68}$. En esta ocasión Lluís fue redimido y una vez vuelto a Orihuela, ante la posibilidad que se produjesen nuevos escándalos con los Masquefa, Fernando II instó a las autoridades del reino a pacificar las partes enemistadas ${ }^{69}$. Así pues, a principios de 1493 se establece una tregua entre los Rocafull y los Masquefa, si bien éstos manifestaron su disgusto ante la absolución y el retorno de Lluís de Rocafull, por lo que el lugarteniente del reino, Joan de Lanuza, a instancias del monarca, hubo de coaccionarlos para que accedieran a firmar el acuerdo ${ }^{70}$. Por otro lado

${ }^{64}$ A.R.V. R.C. reg. 292, ff. 70v-71r (Zaragoza, 2 febrero, 1469).

${ }^{65}$ A.R.V. R.C. reg. 291, ff. 180v-181r (Monzón, 29, marzo, 1470).

${ }^{66}$ A.R.V. R.C. reg. 293, ff 82v-83r (Monzón, 6, julio, 1470).

${ }^{67}$ A.R.V. R.C. reg. 136, f. 109r (Santa Fe, 28, julio, 1491).

${ }_{68}$ A.C.A. R.C. reg. 3571bis, f. 83r (Santa Fe, 16, Julio, 1491).

${ }^{69}$ A.C.A. R.C. reg. 3571 bis, f. 143 r (Barcelona, 14, noviembre, 1492). Desconocemos si Ramón de Rocafull fue absuelto, ya que parece ser que fallece tiempo antes de la firma de las treguas entre los Rocafull y los Masquefa. A.R.V. R.C. reg. 317, f. 33r (Valencia, 10, enero, 1493).

${ }^{70}$ A.R.V. R.C. reg. 317, ff. 28v-29r (Valencia, 7, enero, 1493). En este sentido podemos apuntar que tal vez se accediera a un acuerdo por parte de los Masquefa para ratificar las treguas a cambio de que Lluís de Rocafull abandonase la capital oriolana. Lanzamos esta idea a partir de la información proporcionada por un documento fechado en 1502, por el cual Estefania mujer de Lluís de Rocafull afirma que éste se vio forzado a trasladar su residencia a Xàtiva a causa del conflicto con los Masquefa. A.R.V. R.C. reg. 156, ff. 183r-184r (Valencia, 17, marzo, 1502). 
algunos Rocafull también se negaron a suscribir dicha concordia. En este caso es Enric de Rocafull, señor de Albatera, quien se opuso en un primer momento a ratificar las paces que por tiempo de cuatro años había establecido el lugarteniente del reino ${ }^{71}$.

Los conflictos anteriormente mencionados, tal y como suceden en otros casos conocidos rebasan los límites familiares involucrando así a terceras personas. Se tratan de amigos, vasallos o miembros del servicio doméstico que junto a parientes constituyen una red clientelar que los diferentes linajes se esmeraban en tejer para la defensa de sus intereses ${ }^{72}$. En este sentido hemos de señalar que para los Masquefa las fuentes no nos proporcionan dato alguno sobre sus partidarios más allá de algunos parientes «Nicolau i Francesc Masquefa, germans, Pere Masquefa i sos fills, amics $i$ valedors ${ }^{73}$. En contraposición, por lo que respecta a los Rocamora sí que conocemos ciertos nombres de los individuos que formaron parte de su parcialidad, de este modo excluyendo a los miembros de la familia encontramos entre sus adeptos a Joan Rois, caballero, Jaume Ferrández de Mesa, Antoni y Nicolau Orumbella, Bertomeu y Berenguer Morrelles y Joan d'Ontinyent $^{74}$. Los apellidos mencionados son claramente identificables dentro de aquellos que componen la oligarquía oriolana durante el siglo XV, perteneciendo algunos de ellos al estamento militar y otros al ciudadano ${ }^{75}$. También hemos conseguido identificar a partir de diversas referencias documentales a algunos de los seguidores de los Rocafull. De este modo podemos afirmar que, junto al mencionado anteriormente Martí Maça, contaron con el apoyo de Joan Talavera, Pere Ximenes, menor, y Pere Gomes, quienes aparecen como denunciados por colaborar en el ataque que los Rocafull encabezaron contra el lugar de La Granja, propiedad de mosén Jaume Rocamora ${ }^{76}$.

Más allá de los partidarios de uno y otro bando que se significaron claramente participando de forma activa en los asaltos y tropelías, tanto los Rocamora como los Rocafull contaron con el apoyo de los dos principales nobles con pose-

\footnotetext{
${ }^{71}$ A.R.V. R.C. reg. 137r, ff. 39r-v (Barcelona, 4, noviembre, 1493).

72 Sobre la tipología de los diferentes bandos o linajes urbanos véase: MONSALVO ANTÓN, J. M., «Parentesco y sistema concejil: observaciones sobre la funcionalidad política de los linajes urbanos en Castilla y León (siglos XIII-XV), Hispania: Revista española de historia, vol. 53, No 185, Madrid,1993, pp. 937-969.

${ }^{73}$ A.R.V. R.C. reg. 137r, ff. 39r-v (Barcelona, 4, noviembre, 1493).

${ }^{74}$ A.R.V. R.C. reg. 291, ff. 204v-205r (Monzón 7, mayo, 1470). En el documento también aparecen referenciados mosén Lope Rocamora y sus hijos, mosén Joan Rocamora, e hijos, y mosén Joan Rocamora, menor.

75 BARRIO BARRIO, J. A., «Una oligarquía fronteriza en el mediodía valenciano», Revista d'Història Medieval, 9, València, 1998, pp. 124-125.

${ }^{76}$ A.R.V. R.C. reg. 291, ff. 128v-129r (Tarazona, 28, mayo, 1469).
} 
siones en la gobernación: Joan Roiç de Corella y Pero Maça de Liçana, respectivamente. El caso de éste último es muy significativo ya que el gobernador d'enllà Xixona como pariente de los Rocafull, pues era primo hermano del señor de Albatera, trató de favorecer la causa de sus familiares valiéndose de su posición privilegiada al frente del órgano gubernativo. Este hecho supuso la implicación directa de la institución regia que Maça detentaba, no como instrumento ecuánime del que valerse para la pacificación del territorio, sino decantando el ejercicio de su jurisdicción a favor de una de las parcialidades. En este sentido el someter a contraste los datos existentes procedentes tanto de las fuentes documentales de cancillería como los aportados por el cronista Bellot, quien elabora su obra a partir de actas municipales de la época, hoy desaparecidas, nos permite esbozar el papel desempeñado por Maça en dichas banderías.

El celo puesto por don Pero Maça en la persecución y acoso de los enemigos de los Rocafull, junto a la permisividad mostrada hacia éstos, provocó que tanto los Rocamora como los Masquefa denunciaran en repetidas ocasiones la arbitrariedad con la que ejercía su cargo, incluso años después de que hubieran finalizado las hostilidades, aunque no las tensiones, entre los diferentes protagonistas. Una actuación por la que don Pero Maça llegó a ser suspendido de su cargo temporalmente por el rey quien envió como sustituto a micer Bertomeu Verí, doctor en leyes, para desempeñar la regencia de la gobernación ${ }^{77}$. Pero se ha de señalar que no se denuncia únicamente el mal ejercicio de su cargo y los abusos judiciales de su corte hacia los enemigos de los Rocafull sino también los favores realizados a éstos ${ }^{78}$. Así en 1491 la madre del fallecido Perot Masquefa expone ante el rey como a los Rocafull condenados por la muerte de su hijo no se les habían confiscado sus bienes y que incluso habían sido cobijados por don Pero Maça en sus propias tierras ${ }^{79}$.

Por su parte, el Conde de Concentaina, Joan Roiç de Corella, aparece como valedor de los Rocamora. En este sentido lo encontramos apoyando la denuncia impuesta por Joan Rocamora y otro de sus partidarios, Joan Rois, contra los Ro-

${ }^{77}$ A.R.V. R.C. reg. 138, ff. 62v-63r (Almazán 4, junio, 1496) en HINOJOSA MONTALVO, J., HINOJOSA MONTALVO, J., «Bandos i bandositats en la gobernación de Orihuela..., p. 739. En este documento los Rocamora solicitan al rey que nombre por gobernador a otra persona que no fuera sospechosa de arbitrariedad a favor de los Rocafull ni animadversión hacia ellos, a lo que el monarca recuerda la regencia del cargo de gobernador de Orihuela que desempeñó Bertomeu Verí. Desconocemos el tiempo que duró la regencia pero Bellot señala que la llegada de dicho regente se produjo en 1493 con el objetivo de pacificar la ciudad. BELLOT, mosén Pedro, Anales de Orihuela..., Vol. I, p. 496.

${ }^{78}$ A.C.A. R.C. reg. 3571bis, f. 97v (Real de la Vega de Granada, 22, septiembre de 1491).

${ }^{79}$ A.R.V. R.C. reg. 136, f. 109v (Santa Fe, 28, julio, 1491). 
cafull y sus partidarios por el ataque contra el lugar de la Granja ${ }^{80}$. Así mismo, según indica Bellot, los responsables de las muertes de Antoni Amorós y Ramón de Rocafull logran refugiarse en tierras de Corella, donde consiguieron resistir con apoyo local a los oficiales enviados por el gobernador para apresarlos. Ante tal reacción Maça decide consultar a las autoridades oriolanas sobre la posibilidad de reunir las huestes de la gobernación bajo el pendón real para ir contra las tierras del Conde. El consell de Orihuela se mostró partidario de que se llevase a cabo la acción, por lo que solicitó al monarca, alegando la necesidad de pacificar el territorio, que no pusiera reparo alguno si se llevaba a cabo dicha actuación, a lo cual accedió. Aunque finalmente, parece ser que no hubo de ser necesaria tal acción gracias a la intervención del Adelantado de Murcia quien con su mediación consiguió relajar los ánimos entre ambos nobles ${ }^{81}$.

Por otro lado, el gobierno de la ciudad también se vio afectado por las bandositats en diferentes aspectos. En primer lugar encontramos las repercusiones que se derivan del posicionamiento de algunos de los miembros de las instituciones municipales a favor de uno u otro bando. En este sentido las consecuencias se manifiestan principalmente en la imposibilidad de ejercer sus cargos mientras estuviesen involucrados en el conflicto, bien por estar ausentes de la ciudad o por estar denunciados ${ }^{82}$. Junto a esta situación encontramos otras derivadas de la acción política real que tenía como propósito la pacificación de la ciudad. Son varios los ejemplos que pueden afianzar dicha afirmación como el nombramiento de Jaume Masquefa como justicia criminal, expuesto anteriormente, $\mathrm{u}$ otros como el rechazo por parte del rey a la elección de algunas personas para ejercer cargos municipales ${ }^{83}$. Pero así mismo, Fernando II se valió de este clima de inestabilidad para en 1480 introducir modificaciones en el sistema de insaculación utilizado para la elección de los oficiales municipales, si bien dicha actuación no obtuvo los resultados esperados ${ }^{84}$.

Sin embargo, el intervencionismo regio, que se plasma claramente con la llegada del futuro Fernando II a la localidad oriolana para contribuir a la pacificación de la misma, no afectó solamente al gobierno municipal ${ }^{85}$. De esta manera

${ }^{80}$ A.R.V. R.C. reg. 291, ff. 128v-129r (Tarazona, 28, mayo, 1469).

${ }^{81}$ A.R.V. R.C. reg. 291, ff. 135v-136r (Tarazona, 12, junio, 1469). BELLOT, mosén Pedro, Anales de Orihuela.., Vol. II, pp 114-116.

82 A.R.V. R.C. reg. 292, ff. 97v-98v (Zaragoza, 1 marzo, 1469).

${ }^{83}$ A.R.V. R.C. reg. 293, ff. 157v-158r (Tortosa, 5, febrero, 1471). El rey revoca la elección de Joan d'Ontinyent i Jaume Rabassa por considerar que no son personas «despostes, hàbils ni suficients».

${ }^{84}$ BERNABÉ GIL, D., Monarquía y patriciado urbano en Orihuela 1445-1707, Alicante, 1990, p. 39.

85 A.R.V. R.C. reg. 292, ff. 119v-120r (Monzón, 22, noviembre, 1469). 
la corte del gobernador, ante la ineficacia mostrada por su titular para la resolución del conflicto, que llegó incluso a costarle la suspensión de su cargo, como hemos señalado anteriormente, también sufrió la intromisión de Juan II, quien intercedió en el nombramiento de Jaume Roca, baile general d'enllà Xixona, y de Miquel Sarçola como lugartenientes de don Pero Maça ${ }^{86}$.

\section{CONCLUSIÓN}

La violencia desatada entre algunas de las familias más destacadas de la ciudad oriolana pone de manifiesto las tensiones existentes dentro del grupo social y político dominante. Dicha afirmación se puede observar en la larga duración en el tiempo de esta situación, la cual encuentra en los enfrentamientos armados su momento álgido. En este sentido, si la salvaguarda del honor se convierte en el desencadenante de toda una serie de tropelías encaminadas a la protección del mismo, lo cierto es que detrás de ello se esconden otros factores que no responden únicamente a un factor coyuntural o meramente especifico ${ }^{87}$. De esta manera lo que realmente se dirime en estos enfrentamientos urbanos es, según Marie-Claude Gerbet, el control del poder local $^{88}$. Pero esta máxima necesita de matizaciones particulares en la interpretación del caso anteriormente expuesto, ya que la condición nobiliaria de los Rocafull impedía a sus miembros el poder ejercer cargos municipales. Es por este motivo que dicho linaje tratará de imponer su primacía no sólo desde el punto de vista social sino también político. Aunque para este último aspecto deberán articular mecanismos que les permitan de forma indirecta influir a través de las instituciones, como es el caso de la relación familiar con el titular de la gobernación u otros vínculos que les permitan contar con un conjunto de partidarios dentro de los órganos de gobierno local. Por el contrario tanto los Rocamora como los Masquefa sí que participaran directamente en la administración municipal de la ciudad como miembros de pleno derecho de la misma, lo cual facilitara la utilización de los cargos que desempeñen en su propio provecho, del mismo modo que harán uso de su posición para crear una amplia red de solidaridades e intereses con otras familias o individuos pertenecientes a la oligarquía oriolana.

\footnotetext{
${ }^{86}$ HINOJOSA MONTALVO, J., «Bandos i bandositats en la gobernación de Orihuela..., pp. 735-736.

${ }^{87}$ LALIENA CORBERA, C., IRANZO MUÑíO, M.T., «Poder, honor y linaje en las estrategias de la nobleza urbana aragonesa (siglos XIV-XV)», Revista d'Història Medieval, nº 9, València, 1998, p. 73.

${ }^{88}$ GERBET, M. C., Las noblezas españolas en la Edad Media. Siglos XI-XV. Madrid, 1997, pp. 282-285.
} 
Frente a esta lucha interna encontramos a su vez la acción política de una monarquía preocupada no solo por la pacificación del territorio sino también por el control tanto del estamento nobiliario como de las instituciones ciudadanas, tal y como ha quedado de manifiesto en el caso expuesto. Un intervencionismo regio que utilizará estas luchas urbanas para conseguir dicho propósito en un contexto de fortalecimiento del aparato estatal y por tanto del poder monárquico.

Así pues las disputas nobiliarias ayudaron al rey a entrometerse en los problemas de la clase política nobiliaria a través de soluciones de arbitraje o mediante tribunales judiciales. No podía haber mayor paradoja en esta actitud ni mejor salida, aunque a veces sólo final, para el monarca. Cuanto más luchaban los nobles entre si, cierto es que el peligro de desestabilización política del reino existía o aumentaba, el monarca extendía sus tentáculos en su único objetivo de domesticar los grupos socio-políticos discordantes. Un ejemplo de esta situación de conflictividad nobiliaria entre grandes personajes se puede observar en la casuística expuesta para el valle de Elda. En este caso asistimos a un conflicto jurisdiccional entre el delegado regio y un noble de la zona, donde incluso sus súbditos se niegan a reconocer más autoridad que la de su señor. Nos encontramos por tanto ante una manifestación clara del poder de la nobleza en contraposición no sólo al del rey sino al de sus representantes, en una situación en la que, probablemente, también se entremezclarían aspectos particulares existentes entre ambos nobles más allá del reconocimiento de la autoridad monárquica. De hecho la mediación del rey para solventar ambos conflictos no es otra cosa que un intento más por parte de la Corona de establecer las bases sobre las que posteriormente se asentarían los Estado Modernos, es decir, la creación de una verdadera administración en todos los sentidos, un aparato estatal fuerte y consolidado. Una actuación ésta que afectó principalmente a los municipios y a los señores, principales contrapesos del poder regio. Por ello los siglos bajomedievales en territorio valenciano, desde la conquista cristiana hasta las Germanías, fueron muy complejos desde el punto de vista político y jurisdiccional. De un país en construcción al menos en un siglo o siglo y medio no podemos pasar ipso facto a un Estado Moderno. Los historiadores tenemos que ser cuidadosos y analizar y replantear modelos más que copiarlos. Estas palabras se hacen realidad por las distintas veces que la autoridades oficiales son incapaces, no ya de controlar sino de penetrar incluso físicamente en el dominio señorial en el mismo siglo XV. Diferente imagen nos proporcionan otros episodios a inicios del siglo XVII cuando un sólo alguacil contenía huestes numerosas de individuos. 